University of Nebraska - Lincoln

DigitalCommons@University of Nebraska - Lincoln

Faculty Publications from the Harold W. Manter Laboratory of Parasitology

$2-1974$

\title{
Some Digenetic Trematodes from Synaphobranchid Eels
}

Robin M. Overstreet

Gulf Coast Research Laboratory, robin.overstreet@usm.edu

Douglas M. Martin

Texas A\&M University

Follow this and additional works at: https://digitalcommons.unl.edu/parasitologyfacpubs

Part of the Parasitology Commons

Overstreet, Robin M. and Martin, Douglas M., "Some Digenetic Trematodes from Synaphobranchid Eels" (1974). Faculty Publications from the Harold W. Manter Laboratory of Parasitology. 306.

https://digitalcommons.unl.edu/parasitologyfacpubs/306

This Article is brought to you for free and open access by the Parasitology, Harold W. Manter Laboratory of at DigitalCommons@University of Nebraska - Lincoln. It has been accepted for inclusion in Faculty Publications from the Harold W. Manter Laboratory of Parasitology by an authorized administrator of DigitalCommons@University of Nebraska - Lincoln. 


\title{
SOME DIGENETIC TREMATODES FROM SYNAPHOBRANCHID EELS*
}

\author{
Robin M. Overstreet $\dagger$ and Douglas M. Martin $\ddagger$
}

ABSTRACT: Four trematodes, all new host records, were found in synaphobranchid eels from the continental slopes in the Gulf of Mexico and the Straits of Florida. Hypertrema ambovatum Manter, 1960 (Fellodistomidae), previously known only from near New Zealand, is reported from Synaphobranchus oregoni, including data in addition to the original description; Pseudopecoelus vulgaris (Manter, 1934) (Opecoelidae) and Hirudinella sp. (Hirudinellidae) are reported from S. affinis and S. oregoni, respectively, and commented upon briefly; and Helicometra robinsorum sp. n. (Opecoelidae) is described from S. oregoni and Ilyophis brunneus. The latter trematode most closely resembles $\mathrm{H}$. antarcticae Holloway and Bier, 1968, from which it differs by having a sucker-width ratio of 1:1.7 to 2.1 rather than $1: 1.2$, a subterminal rather than terminal oral sucker, a cirrus sac extending to the posterior border rather than middle of the acetabulum, and eggs that are usually smaller.

Digenetic trematodes parasitize synaphobranchid eels (Yamaguti, 1938; Guiart, 1938; Manter, 1947; and the present study). These eels, benthic inhabitants of the continental slopes of temperate and tropical waters, are characterized by having scales and possessing either a single slitlike branchial aperture on the midline of the throat or two restricted ventral openings. Many such eels 330 to 776 $\mathrm{mm}$ in length were collected by the $\mathrm{R} / \mathrm{V}$ Alaminos along the continental slopes of the Gulf of Mexico and the Caribbean Sea in water 620 to $2,150 \mathrm{~m}$ deep, including 134 specimens of Synaphobranchus oregoni Castle, eight of S. brevidorsalis Günther, one of $S$. affinis Günther, and eight of Ilyophis brunneus Gilbert. Digenea occurred in members of the first and last species in the Gulf of Mexico as well as in additional individuals from the Straits of Florida given to us by Catherine $\mathrm{H}$. Robins. All are new host records.

Fishes were slit and then fixed in $10 \%$ formalin as soon as they were brought aboard the vessel; however, trematodes could have moved to their cited location in the host before or during fixation. Trematodes removed from preserved fishes and later transferred to AFA included many favorable specimens that

Received for publication 3 August 1973.

* This work is a result of research sponsored in part by NOAA Office of Sea Grant, Department of Commerce Grant No. 04-3-158, Publication MASGP-73-003. The U. S. Government is authorized to produce and distribute reprints for governmental purposes notwithstanding any copyright notation that may appear hereon.

$\dagger$ Gulf Coast Research Laboratory, Ocean Springs, Mississippi 39564.

$\ddagger$ Department of Oceanography, Texas A \& M University, College Station, Texas 77843. stained well with Van Cleave's hematoxylin. Two individuals were sectioned and stained with Harris' hematoxylin and eosin, and all material was mounted in Permount. Figures, except those designated otherwise, were drawn with the aid of a camera lucida. Measurements are given in microns.

\section{Family Fellodistomidae \\ Hypertrema ambovatum Manter, 1960}

(Figs. 1-4)

Supplement to original description based on 11 mounted and 1 sectioned specimen. Body 1,938 to 3,503 long by 1,614 to 2,840 wide with maximum width at or near midbody. Numerous eosinophilic, possibly adhesive, gland cells near tegumental margins, most dense ventrally. Oral sucker 256 to 402 long by 316 to 436 wide. Acetabulum, usually withdrawn into middle of body, 436 to 731 long by 477 to 731 wide. Sucker-width ratio $1: 1.5$ to 2.0 . Forebody 24 to $38 \%$ of body length. Pharynx 128 to 209 long by 102 to 155 wide. Prepharynx shorter than $1 / 2$ width of pharynx. Ceca occasionally extending beyond acetabulum to midtesticular level. Testes near midbody, partially or entirely lateral, smooth, of various shapes such as pyriform, reniform, and sausage-shaped, curved, straight, or folded; right testis 339 to 938 long by 316 to 511 wide; left testis 339 to 800 by 345 to 963. Cirrus sac (Fig. 1) often constricted near middle; distal portion bulbous, containing ejaculatory duct, prostatic duct, distal portion of tripartite seminal vesicle, and numerous narrow, elongated, small-nucleated prostatic cells; proximal portion usually distinct unless swollen with sperm, containing globular or elongated proximal and elongated middle portions of seminal vesicle and few, if any, prostatic cells. Ovaries 3, subspherical, largest in each worm 293 to 356 long by 189 to 304 wide, with short oviducts joining to form short common duct. Mehlis' gland conspicuous, surrounding proximal portions of Laurer's canal, uterus, vitelline ducts, and occasionally oviduct; smaller additional glandular cells surrounding Laurer's canal. Seminal receptacle lacking, proxi- 


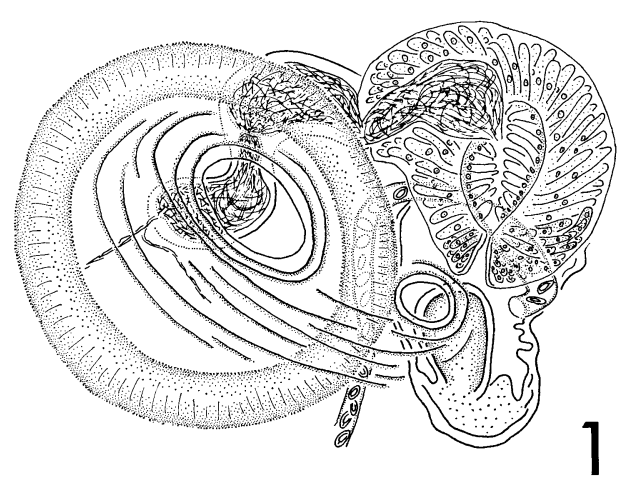

FIGURE 1. Hypertrema ambovatum, terminal genitalia, composite illustration of two specimens, ventral view.

mal portion of uterus acting as uterine seminal receptacle. Vitelline follicles either lateral to or surrounding ceca, occasionally extending into pharyngeal level and beyond testicular level. Genital atrium sinistral, at acetabular level, thick-walled, a continuation of muscular lining of cirrus sac, controlled by numerous dorsoventral and diagonal muscle fibers, containing large muscular papilla directed laterally to anteriorly; uterus entering laterally by short metraterm. Eggs with outer shell 26 to 59 long by 16 to 29 wide, inner shell up to 47 long.

Host: Synaphobranchus oregoni.

Sites: Stomach and intestine.

Intensity: 1 to 12 per infected host.

Incidence and localities: 6 of 14 at lat $19^{\circ} 00.3^{\prime}$ $\mathrm{N}$, long $95^{\circ} 11.1^{\prime} \mathrm{W}$ in 1,097 to $1,134 \mathrm{~m} ; 1$ of 8 at lat $29^{\circ} 10.5^{\prime} \mathrm{N}$, long $87^{\circ} 16^{\prime} \mathrm{W}$ in $914 \mathrm{~m}$ (Gulf of Mexico).

Specimen deposited: USNM Helm. Coll. No. 72846.

\section{DISCUSSION}

The only other description (Manter, 1960) of this fellodistomid is brief and concerns specimens recovered from Simenchelys parasiticus Gill collected near New Zealand. Preceding data complement Manter's, agreeing in most respects with the original description and with whole mounts and sections from his collection. Minor variations existed such as larger testes and the lack of a constricted cirrus sac with a conspicuous tripartite seminal vesicle in some worms from New Zealand.

The ceca in our specimens are unusual. One cecum of the sectioned individual possessed hypertrophied columnar epithelial cells (Fig. 2 ), some of which were vacuolated. The lumen was filled with some vacuolar material.

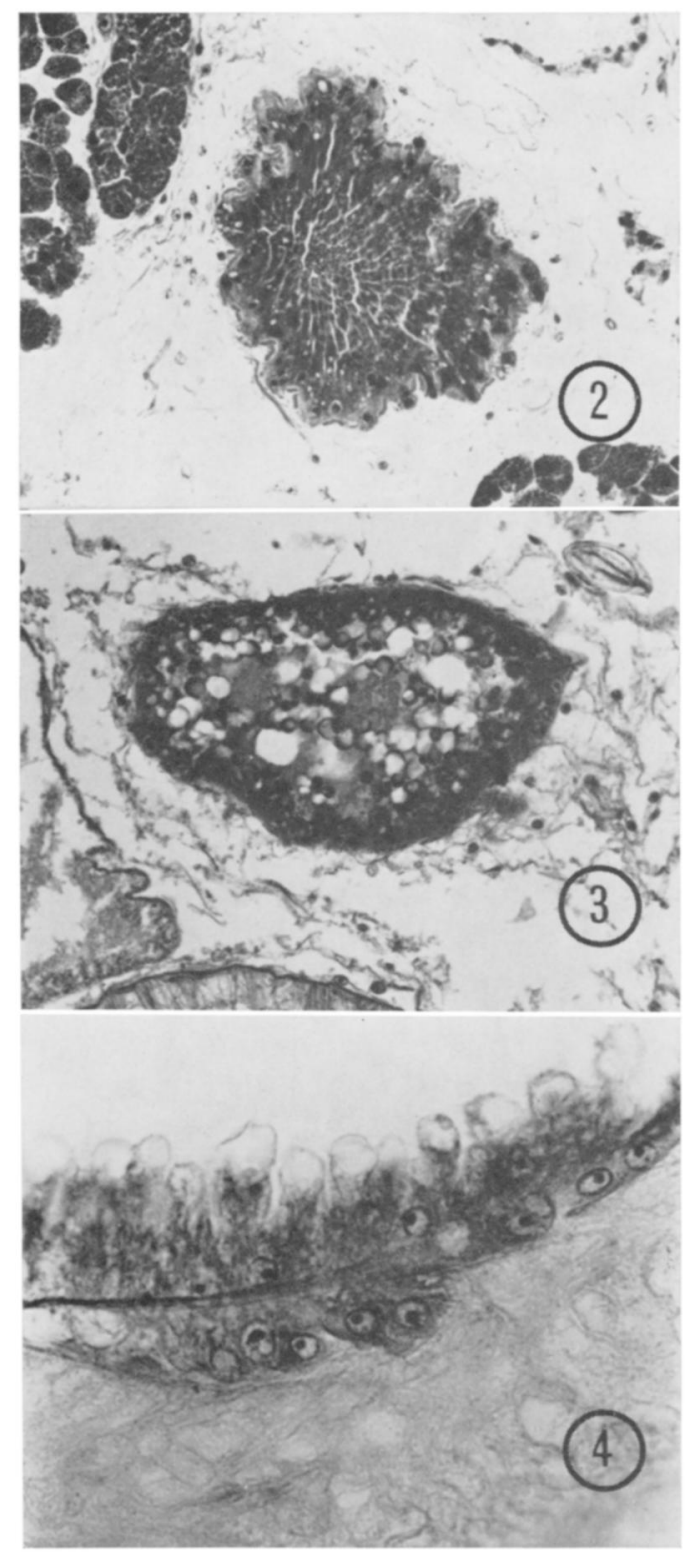

Figures 2-4. Cross sections of Hypertrema ambovatum. 2. Cecum of specimen from Synaphobranchus oregoni at acetabular level. 3. Opposite cecum of same specimen at same level. 4. Cecal epithelium of specimen from Simenchelys parasiticus.

In contrast, the epithelium of the opposite cecum was cuboidal (Fig. 3), producing a more copious amount of the vacuolated material. Underlying the epithelium of both ceca was a thin lining of hyaline degeneration. The homogeneous, glassy eosinophilic, cytoplasmic 


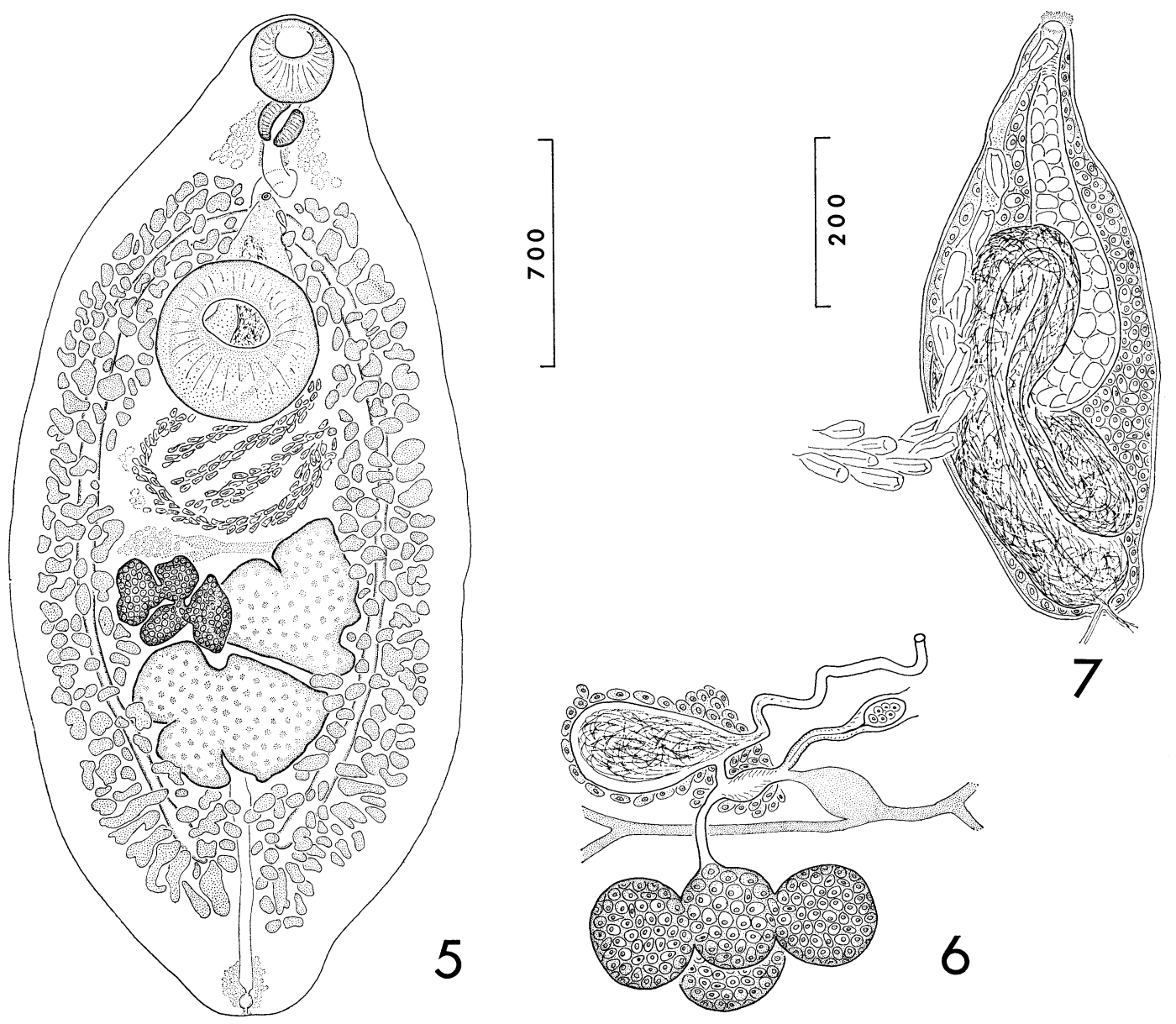

Figures 5-7. Helicometra robinsorum. 5. Holotype, ventral view. 6. Ovarian complex reconstructed from cross-sectioned specimen, ovary is ventral. 7. Terminal genitalia, dorsal veiw.

layer consisted of disjunct areas typically 6 to $12 \mu$ wide by $2 \mu$ deep. The ceca in our whole mounts also contained hypertrophied epithelial cells, whereas those in a sectioned specimen from S. parasiticus were "normal" in height, but contained numerous vacuoles (Fig. 4). No hyaline degeneration occurred. Unusual in that specimen, however, was a discontinuous basal lamina with epithelial cells often encroaching on the underlying parenchymal tissue (Fig. 4). Worms from both hosts produced numerous normal eggs, a finding which suggests the worms received proper nutrients. The difference between specimens from the two hosts, not considered by us as an artifact or postmortem change, could be dependent on the host, the worm, or the worm's diet. According to Gresson and Threadgold (1959), the intestinal epithelium of Fasciola hepatica $\mathrm{L}$. is elongated when food is absent. Harris and Cheng (1973) commented on increased lipid production in starved trematodes and showed that lipid droplets in projections of cecal epithelium increased dramatically in Leucochloridiomorpha constantiae (Mueller, 1935) transferred from 3 to $4 \mathrm{C}$ to 22 to $25 \mathrm{C}$ and examined at that temperature at intervals between 12 and 84 hr. Histological methods such as we used would remove lipids, leaving vacuoles. Presumably, because of the pathological changes, a more complicated situation exists for our specimens.

Life history data on this worm remain un- 
known. The trematode is presumably fairly host-specific, since it is known from the two related hosts only. According to Robins and Robins (1970), "Simenchelys easily could be placed in the family Synaphobranchidae." Simenchelys parasiticus, as its specific name implies and a general text reports (Marshall, 1965), fastens itself to other fishes and chews out pieces of flesh. Nine of 12 individuals examined in this study contained food. Careful analysis of stomach contents revealed nothing but tissue of fishes with a scarcity of bones and scales. When whole fishes, which in conjunction with crustaceans constitute the typical diet in other synaphobranchids, are eaten, bones, scales, and eye lenses are common. Either the intermediate host is a fish, or the presence of Hypertrema ambovatum acts as a good indicator of an as yet undetected food item for $S$. parasiticus.

\section{Family Opecoelidae Helicometra robinsorum sp. $n$.} (Figs. 5-7)

Description based on 12 whole mounts, 1 later sectioned. Body pyriform to fusiform, more tapered anteriorly, 1,595 to 2,990 long by 792 to 1,369 wide, maximal width at acetabulotesticular region. Oral sucker with ventral aperture, nearly spherical, 193 to 258 long by 191 to 261 wide. Acetabulum rounded with circular to slightly transverse aperture, 333 to 485 long by 348 to 511 wide. Suckerwidth ratio $1: 1.7$ to 2.1 . Forebody 419 to 738 or 20 to $29 \%$ of body length. Pharynx 73 to 133 long by 93 to 131 wide. Prepharynx shorter than pharynx. Esophagus longer, sometimes over $2 \times$, than pharynx, often looped. Small gland cells surrounding esophagus; larger ones lateral to those and to pharynx filled with granular material, with associated eosinophilic substance in ductlike structures leading into pharynx. Intestinal bifurcation anterior to acetabulum; ceca terminating between 10 and $26 \%$ of body length from posterior end.

Testes lobed to irregular in shape, diagonal, usually slightly separated; anteriormost testis more sinistral than posterior one, 258 to 465 long by 287 to 477 wide; posteriormost testis 239 to 497 by 396 to 643 . Posttesticular space 10 to $24 \%$ of body length. Cirrus sac clavate, dorsal to acetabulum and extending from near intestinal bifurcation to or slightly past level of posterior border of acetabulum, 450 to 666 long by 201 to 318 wide; containing convoluted tubular seminal vesicle usually filling much of posterior $1 / 2$ to $2 / 3$ of sac, prostatic vesicle surrounded by numerous prostatic cells. Solid core, as indicated in Figure 7 , within seminal vesicle of at least some individuals, extending from near wider proximal end to male duct. Vasa efferentia entering together at base of cirrus sac. Genital pore medial, near intestinal bifurcation.

Ovary with 4 primary lobes, each sometimes possessing secondary lobes, ventral, dextral, usually anterior to rear testis and adjacent to forward one, 210 to 322 long by 206 to 431 wide; anterior border 49 to $59 \%$ of body length from anterior of worm. Mehlis' gland and vitelline reservoir conspicuous, seminal receptacle and ootype usually inconspicuous. Laurer's canal long, thick-walled, opening dorsally near ovarian level. Vitelline follicles surrounding ceca, extending in lateral bands between near posterior end of body and anterior to acetabulum, typically well separated posteriorly but occasionally almost confluent, sometimes confluent anteriorly. Uterus with no more than 8 coils; metraterm typically dorsal and to left of midline of cirrus sac, surrounded by glandular cells. Eggs numerous, partially collapsed, 44 to 74 long by 22 to 35 wide with filaments between 316 and 517 or between 6 and $9 \times$ length of capsule, presumably longer filaments occurring.

Excretory vesicle I-shaped, extending to or near ovarian level; pore terminal, associated with muscular sphincter and numerous glandular cells.

Hosts: Synaphobranchus oregoni, type host; Ilyophis brunneus.

Sites: Stomach and intestine.

Intensity: 1 to 5 per infected host.

Incidence and localities: S. oregoni: 1 of 14 at lat $19^{\circ} 00.3^{\prime} \mathrm{N}$, long $95^{\circ} 11.1^{\prime} \mathrm{W}$ in 1,097 to 1,134 $\mathrm{m}$ (type locality) and 1 of 8 at lat $29^{\circ} 10.5^{\prime} \mathrm{N}$, long $87^{\circ} 16^{\prime} \mathrm{W}$ in $914 \mathrm{~m}$ in the Gulf of Mexico; 1 of 1 at lat $24^{\circ} 24^{\prime}$ to $28^{\prime} \mathrm{N}$, long $80^{\circ} 22^{\prime}$ to $16^{\prime} \mathrm{W}$ in $805 \mathrm{~m}$ in Straits of Florida. I. brunneus: 2 of 2 at lat $29^{\circ} 03^{\prime} \mathrm{N}$, long $87^{\circ} 15^{\prime} \mathrm{W}$ in $1,061 \mathrm{~m}$ in the Gulf of Mexico and 1 of 2 at lat $24^{\circ} 23^{\prime}$ to $29^{\prime} \mathrm{N}$, long $80^{\circ} 28^{\prime}$ to $18^{\prime} \mathrm{W}$ in $786 \mathrm{~m}$ in Straits of Florida.

Holotype: USNM Helm. Coll. No. 72847. Paratypes: No. 72848 and University of Nebraska State Museum, Manter Lab. No. 20030.

The name robinsorum is in honor of Drs. Catherine $\mathrm{H}$. and C. Richard Robins of the Rosenstiel School of Marine and Atmospheric Sciences, University of Miami, for their contributions to the field of ichthyology.

\section{DISCUSSION}

Considering species of Helicometra Odhner, 1902, with testes oblique, ovary lobed, cirrus sac not extending well posterior to the acetabulum, and vitelline follicles typically nonconfluent in the hindbody and present anterior to the acetabulum, $H$. robinsorum resembles most another species from a low-temperature habitat, $H$. antarcticae Holloway and Bier, 1968 , from which it differs in several respects. The sucker-width ratio differs, $1: 1.7$ to 2.1 
compared to $1: 1.2$; the oral sucker is subterminal; the cirrus sac extends to the posterior border of the acetabulum rather than its middle; and the eggs are usually smaller. In two other species, H. epinepheli Yamaguti, 1934, which Durio and Manter (1968) regarded as a synonym of $H$. fasciata (Rudolphi, 1819), and H. marwewitschi Pogorel'tseva, 1954, the testes are occasionally diagonal, but the sucker ratio is less and the cirrus sac does not extend to the posterior border of the acetabulum. Other differences include an intertesticular ovary in H. markewitschi and an excretory vesicle extending anteriorly beyond the acetabulum in $H$. epinepheli.

\section{Pseudopecoelus vulgaris (Manter, 1934)} Von Wicklen, 1946

Host: Synaphobranchus affinis.

Sites: Stomach and intestine.

Locality: Lat $26^{\circ} 10^{\prime}$ to $24^{\prime} \mathrm{N}$, long $79^{\circ} 37^{\prime}$ to $39^{\prime} \mathrm{W}$ in 686 to $699 \mathrm{~m}$ (Straits of Florida).

\section{DISCUSSION}

Three specimens 1.87 to $3.81 \mathrm{~mm}$ long with sucker-width ratios $1: 1.8$ to 2.2 and eggs 116 to $130 \mu$ long by 67 to $81 \mu$ wide agreed with those described by Manter (1934) from 16 different hosts also caught in deep water off Florida. The same species has also been reported from fishes off New Zealand (Manter, 1954) and Senegal, West Africa (Fischthal and Thomas, 1972).

\section{Family Hirudinellidae Hirudinella sp.}

Host: Synaphobranchus oregoni.

Site: body cavity.

Incidence and locality: 1 of 14 at lat $19^{\circ} 00.3^{\prime}$ $\mathrm{N}$, long $95^{\circ} 11.1^{\prime} \mathrm{W}$ (Gulf of Mexico).

\section{DISCUSSION}

A single specimen $16.4 \mathrm{~mm}$ long by 2.28 $\mathrm{mm}$ at the acetabular, or widest, level and not developed sufficiently to identify possibly penetrated into the body cavity as an accidental infection. It had a few poorly formed eggs up to $29 \mu$ long by $23 \mu$ wide, and the ceca were distended posteriorly with hematinlike ingesta.

\section{ACKNOWLEDGMENTS}

We are grateful to Catherine $\mathrm{H}$. Robins for information on eel feeding behavior and the gift of five trematodes and to Mary Hanson Pritchard for the loan of material. Theresa Ann St. Andrie, Edward C. Whatley, Jr., and Ronnie G. Palmer provided technical assistance.

\section{LITERATURE CITED}

Durio, W. O., and H. W. Manter. 1968. Some digenetic trematodes of marine fishes of New Caledonia. Part II. Opecoelidae and Lepocreadiidae. J. Parasit. 54: 747-756.

Fischthal, J. H., and J. D. Thomas. 1972. Digenetic trematodes of marine fishes from Senegal. Bull. IFAN 34, Ser. A: 292-322.

Gresson, R. A. R., and L. T. Threadgold. 1959. A light and electron microscope study of the epithelial cells of the gut of Fasciola hepatica L. J. Biophys. Biochem. Cytol. 6: 157-162.

Guiart, J. 1938. Trématodes parasites provenant des Campagnes scientifiques du Prince Albert $\mathrm{I}^{\text {er }}$ de Monaco (1886-1912). Résult. Camp. Sci. Albert $\mathrm{I}^{\mathrm{er}}$ Prince Monaco, fasc. C, 75: 76-84.

Harris, K. R., and T. C. Cheng. 1973. Histochemical demonstrations of fats associated with intestinal caeca of Leucochloridiomorpha constantiae. Tr. Am. Micr. Soc. 92: 496-502.

Manter, H. W. 1934. Some digenetic trematodes from deep-water fish of Tortugas, Florida. Publ. (435) Carnegie Inst. Wash., Pap. Tortugas Lab. 28: 257-345.

- 1947. The digenetic trematodes of marine fishes of Tortugas, Florida. Am. Midl. Nat. 38: 257-416.

- 1954. Some digenetic trematodes from fishes of New Zealand. Tr. Roy. Soc. New Zealand 82: $475-568$.

- 1960. Some additional Digenea (Trematoda) from New Zealand fishes. Lib. Hom. E. Caballero y C.: 197-201.

Marshall, N. B. 1965. The Life of Fishes. Weidenfeld and Nicolson, London, $402 \mathrm{p}$.

Robins, Catherine H., and C. R. Robins. 1970. The eel family Dysommidae (including the Dysomminidae and Nettodaridae), its osteology and composition, including a new genus and species. Proc. Acad. Nat. Sci. Phila. 122: 293-335.

YamaGUTI, S. 1938. Studies on the Helminth Fauna of Japan. Part 21. Trematodes of Fishes, IV. Publ. by author, 139 p. 